\title{
Long-term memory of subduction processes in the lithospheric mantle: evidence from the geochemistry of basic dykes in the Gardar Province of South Greenland
}

\author{
K. M. GOOdENOUGH ${ }^{1,3}$, B. G. J. UPTON ${ }^{1}$ \& R. M. ELLAM ${ }^{2}$ \\ ${ }^{1}$ Department of Geology and Geophysics, University of Edinburgh, West Mains Road, Edinburgh EH9 3JW, UK \\ ${ }^{2}$ Isotope Geoscience Unit, SURRC, East Kilbride G75 OQF, UK \\ ${ }^{3}$ Present address: British Geological Survey, Murchison House, West Mains Road, Edinburgh EH9 3LA, UK \\ (e-mail:kmgo@bgs.ac.uk)
}

\begin{abstract}
The rift-related magmas of the Proterozoic Gardar Igneous Province were emplaced across the contact between the South Greenland Archaean craton and the Palaeoproterozoic Ketilidian mobile belt. It has been suggested that the geochemistry of Gardar intrusive rocks in the two areas varies across the craton margin and that this reflects a lithospheric control. However, comparison of the geochemical and isotopic signatures of basic and ultrabasic dykes from across the area shows that there is no systematic variation related to the age of the country rock. All the Gardar basic rocks are inferred to have been derived from the mantle, with relatively little crustal contamination. We suggest that the lithospheric mantle beneath the Gardar Province was enriched by slab-derived fluids during the Ketilidian orogeny (c. $1800 \mathrm{Ma}$ ). Subsequent melting of this mantle source was promoted during Gardar rifting when volatile-rich, small-degree melts from the asthenosphere were introduced into the lithospheric mantle, forming enriched metasomites. Ultrabasic lamprophyre dykes in the Gardar Province represent melts derived largely from these metasomites, whereas basaltic magmas were formed by larger-scale melting of the lithospheric mantle, inheriting a subductionrelated signature. There is no evidence that the Gardar magmas were derived from a highly enriched lithospheric keel that had existed since craton formation.
\end{abstract}

Keywords: Greenland, Gardar, igneous intrusions, geochemistry.

The Gardar Igneous Province of SW Greenland was formed during a period of intraplate alkaline magmatism, related to continental rifting, between 1350 and $1150 \mathrm{Ma}$ ago (Blaxland et al. 1978; Paslick et al. 1993). The Province comprises some 10 major central complexes, together with a volcanic succession and numerous minor intrusions, exposed over an area of about $70 \mathrm{~km}$ by $200 \mathrm{~km}$ (Fig. 1). The dominant magma types are basalts and hawaiites, with lesser amounts of trachytes, quartz trachytes, alkali rhyolites and phonolites. Subordinate volumes of carbonatite and lamprophyre magmas are also present. Reviews of the geology of the Province have been published by Upton (1974), Emeleus \& Upton (1976), Upton \& Emeleus (1987) and Macdonald \& Upton (1993).

The Gardar Province straddles the margin between a Proterozoic mobile belt (the Ketilidian) and the South Greenland Archaean craton (Fig. 1). The country rocks underlying most of the Gardar Province are Proterozoic granites of the Julianehåb batholith, which constitutes a major part of the basement of the Ketilidian mobile belt (Windley 1991; Chadwick \& Garde 1996). However, the northwestern part of the Province (the Ivittuut area)

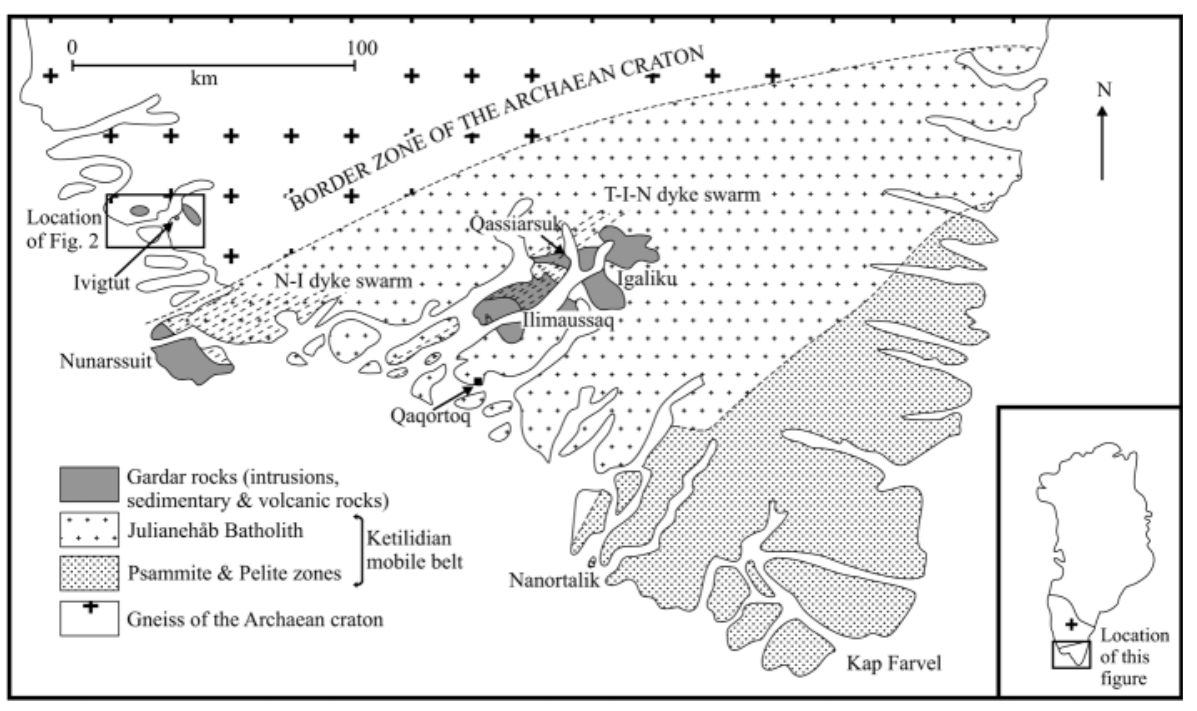

Fig. 1. Simplified geological map of southern Greenland, after Chadwick \& Garde (1996), showing the principal divisions of the Ketilidian orogen and the location of the main areas of Gardar rocks. The Nunarssuit-Isortôq $(\mathrm{N}-\mathrm{I})$ and Tugtutôq-Ilímaussaq-Nunataq (T-I-N) dyke swarms are shown diagrammatically. 
lies within the Border Zone of the Archaean craton, which has been variably affected by Ketilidian deformation and metamorphism (Chadwick \& Garde 1996).

Gabbroic and doleritic dykes, which are common throughout the Gardar Province, were formed by the intrusion of transitional olivine basaltic and hawaiitic magmas (Upton \& Emeleus 1987). Alkaline and ultramafic lamprophyres are also found as dykes, but are less common. Upton \& Blundell (1978) proposed that three cycles of Gardar activity can be recognized, each commencing with basaltic magmatism and ending with emplacement of more evolved plutons. During the early Gardar period, around $1350 \mathrm{Ma}$ (Paslick et al. 1993), basaltic lavas were erupted and syenitic plutons were emplaced. During the mid-Gardar period, swarms of doleritic dykes were emplaced, together with subordinate alkaline and ultramafic lamprophyres. These are concentrated along the margin of the Archaean craton and so are common in the Ivittuut area. Late Gardar basic magmatism was concentrated in two SW-NE-trending zones within the Ketilidian mobile belt: the Nunarssuit-Isortôq zone in the west and the Tugtutôq-Ilímaussaq-Nunataq zone in the east. Both of these zones are characterized by the presence of 'Giant Dykes' up to 800 m wide (Upton \& Emeleus 1987).

Upton \& Emeleus (1987) noted that the Gardar basic magmas tend to show relative compositional uniformity in time and space across the Province, and pointed out that their high mean $\mathrm{Al}_{2} \mathrm{O}_{3}$ / $\mathrm{CaO}$ ratios distinguish them from both the preceding Ketilidian and subsequent Phanerozoic basaltic rocks in southern Greenland. The basaltic magmas were inferred to have been derived from cpx-poor garnet lherzolites or harzburgites, rendered more fusible by metasomatic enrichment. As the basaltic magmas rarely have $\mathrm{MgO}$ contents $>8 \mathrm{wt} \%$, Upton \& Emeleus (1987) suggested that extensive continental underplating accompanied the rift episodes and that only relatively fractionated melt products reached high crustal levels. By contrast, the volumetrically insignificant lamprophyric magmas were capable of reaching shallow crustal levels in much more primitive states. Their more magnesian character $(\mathrm{MgO}>8 \%)$, together with the observation that some carry mantle xenoliths, implies higher ascent rates, probably attributable to higher volatile contents.

The mantle-normalized incompatible element patterns of many Gardar basaltic rocks differ from those of ocean island basalt (OIB), having notable negative $\mathrm{Nb}$ anomalies as well as positive $\mathrm{Rb}, \mathrm{K}, \mathrm{Ba}$ and light rare earth (LREE) anomalies. This led Upton \& Emeleus (1987) to postulate that the basaltic magmas originated through melting of a lithospheric mantle source. Magma genesis from formerly refractory lithospheric peridotites was inferred to have been initiated by infiltration of F-, Cl- and $\mathrm{CO}_{2}-$ rich fluids from the deep mantle, promoting metasomatism and partial melting.

Upton \& Emeleus (1987) also suggested that the Gardar magmas intruded into the Archaean craton were geochemically distinct from those intruded into the Ketilidian rocks. This paper presents new data for the doleritic and lamprophyric Gardar dykes intruding the Border Zone of the craton, and compares these with similar Gardar dykes within the Julianehåb batholith, to assess the effects of lithospheric control on their geochemistry.

\section{Geology of the Ivittuut area}

The Border Zone of the Archaean craton is intruded by three Gardar central complexes: the Ivigtut granite (Bailey 1980; Pauly \& Bailey 1999; Goodenough et al. 2000); the Kûngnât syenitegabbro complex (Upton 1960); and the Grønnedal-Íka nepheline syenite-carbonatite complex (Emeleus 1964; Bedford 1989) (Fig. 2). Dyke swarms in the area comprise mainly olivine dolerites and lamprophyres, although some more evolved dykes also occur. The field relations and petrography of these dykes have been summarized by Berthelsen \& Henriksen (1975).

The oldest Gardar intrusions in the Border Zone are NE-easttrending lamprophyric dykes, which are most abundant in a zone of mineralization and faulting on the Ivittuut peninsula (Berthelsen 1962). These lamprophyres are typically porphyritic,

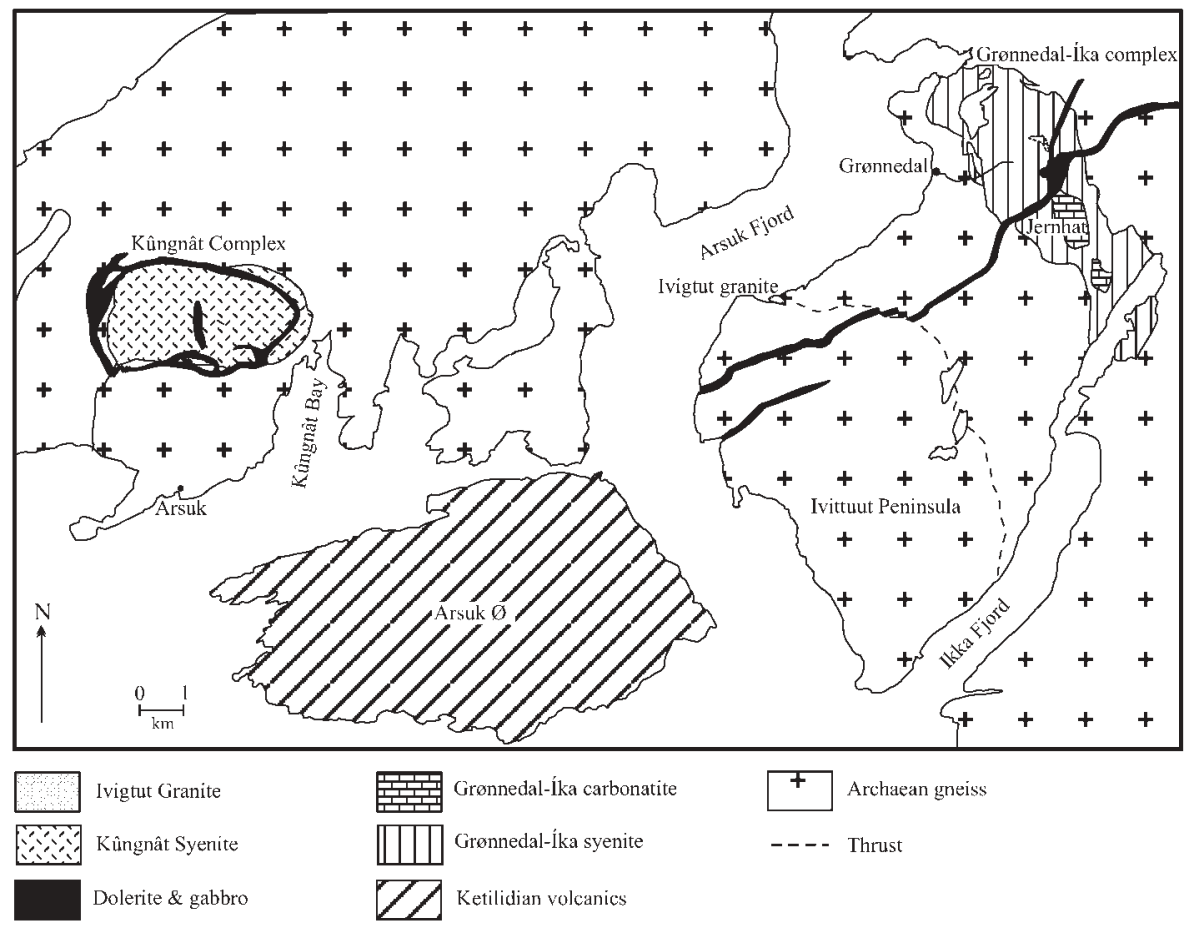

Fig. 2. Simplified geological map of the Ivittuut area, showing the main Gardar rocks. Only the largest dykes are indicated. 
with phenocrysts of hornblende, biotite, augite or sericitized plagioclase in a fine-grained groundmass composed principally of biotite, hornblende, opaque oxides, chlorite and carbonate. In some dykes, clinopyroxenes and feldspars are found in the groundmass. Most of the lamprophyres contain ocelli, which are filled with carbonates and/or chlorite.

Olivine dolerite dykes, up to $200 \mathrm{~m}$ wide, are abundant in the Ivittuut area and are referred to in the literature as 'brown dykes' because of their brown, rubbly weathering. The trend of the oldest dykes is roughly east-west, with younger dykes trending progressively more northeastwards (Berthelsen 1962). They typically comprise early olivine and plagioclase, ophitically enclosed by augite, with opaque oxides and apatite. In parts of the Ivittuut area, the dolerites have been hydrothermally altered, and much of the primary assemblage has been partly replaced by chlorite and epidote.

Other basic dykes in the Ivittuut area include a group of micro-porphyritic basaltic dykes, which are younger than the brown dykes (Emeleus 1964). They are typically thin (up to $2 \mathrm{~m}$ wide) and comprise plagioclase phenocrysts in a fine-grained olivine-free groundmass of augite and andesine.

\section{Analytical methods}

Bulk-rock samples of all the dyke types from the Ivittuut area were selected for geochemical analysis on the basis of petrographic study (Goodenough 1997), and representative subsets of these were further analysed for rare earth elements (REE) and selected for isotope analysis. Major and trace element concentrations were determined by XRF at the Department of Geology and Geophysics, University of Edinburgh, following the method described by Fitton et al. (1998). For a subset of the samples, REE were analysed by inductively coupled plasma atomic emission spectrometry (ICP-AES) at the Department of Geology, Royal Holloway, University of London, following the method of Walsh et al. (1981). Radiogenic isotopes were analysed at SURRC, East Kilbride. Rb, $\mathrm{Sr}, \mathrm{Sm}$ and Nd were separated using conventional ion-exchange techniques. $\mathrm{Rb}$ and $\mathrm{Sr}$ were analysed on a VG 54E single-collector thermal ionization mass spectrometer, which gave $\mathrm{NBS} 987{ }^{87} \mathrm{Sr} /{ }^{86} \mathrm{Sr}=$ $0.71024 \pm 6$ (2 SD $n=19$ ); some Sr samples were run on a VG Sector 54-30 multiple-collector mass spectrometer, which gave NBS987 ${ }^{87} \mathrm{Sr} /{ }^{86} \mathrm{Sr}=0.710237 \pm 20(2 \mathrm{SD} n=21) . \mathrm{Sm}$ and $\mathrm{Nd}$ were analysed on the VG Sector 54-30 instrument, which gave ${ }^{143} \mathrm{Nd} /{ }^{144} \mathrm{Nd}=$ $0.511501 \pm 9(2 \mathrm{SD} n=20)$ for the internal JM Nd standard. Analytical uncertainties (2 SD) are c. $1 \%$ or better on ${ }^{87} \mathrm{Rb} /{ }^{86} \mathrm{Sr}$ and $0.2 \%$ or better on ${ }^{147} \mathrm{Sm} /{ }^{144} \mathrm{Nd}$, and c. $0.002 \%$ on ${ }^{87} \mathrm{Sr} /{ }^{86} \mathrm{Sr}$ and $0.001 \%$ on ${ }^{143} \mathrm{Nd} /{ }^{144} \mathrm{Nd}$. All the samples were run during a period of 9 months in 1996.

\section{Geochemistry of doleritic and lamprophyric Gardar dykes of the Ivittuut area}

The lamprophyre dykes are the most primitive of the Gardar intrusions, with $\mathrm{SiO}_{2}$ contents of $35-42 \mathrm{wt} \%$ and $\mathrm{MgO}$ up to $15 \mathrm{wt} \%$ (Table 1). The basaltic dykes are typically more evolved, with $\mathrm{SiO}_{2}$ contents up to $50 \mathrm{wt} \%$ and $\mathrm{MgO}<8 \mathrm{wt} \%$. Normative compositions, calculated on the basis of an $\mathrm{Fe}_{2} \mathrm{O}_{3} /\left(\mathrm{FeO}+\mathrm{Fe}_{2} \mathrm{O}_{3}\right)$ ratio of 0.15 (Upton 1960) permit further subdivisions of the dyke groups. The lamprophyres can be subdivided into two groups, following the classification of Rock (1987): alkaline lamprophyres (lacking normative larnite) and ultramafic lamprophyres (with normative larnite). The alkaline lamprophyres typically contain small amounts of feldspar, and are kersantites and spessartites under the classification of Le Maitre (1989) whereas the ultramafic lamprophyres are feldspar-free aillikites. Similarly, the basaltic dykes can be subdivided into hypersthenenormative and nepheline-normative groups.

Trace element compositions provide a greater insight into the variations among the Gardar basic and ultrabasic rocks. The lamprophyres in the Ivittuut area generally have similar trace element compositions to those of the Tugtutôq-IlímaussaqNunataq zone within the Ketildian mobile belt (Upton \& Emeleus 1987). They have high contents of $\mathrm{Ni}, \mathrm{Cr}, \mathrm{Ba}, \mathrm{Sr}, \mathrm{Nb}$ and $\mathrm{Th}$ (Table 1; Fig. 3a), with $\mathrm{Zr} / \mathrm{Nb}$ ratios of about four and $\mathrm{La} / \mathrm{Nb}$ ratios $<0.75$. They are also highly enriched in the LREE, with $(\mathrm{La} / \mathrm{Lu})_{\mathrm{N}}$ values of c. 28 (Table 2; Fig. 4).

The basaltic dykes show a wider variation in trace element compositions (Fig. 3b and c), but typically have lower contents of $\mathrm{Ni}, \mathrm{Cr}$ and $\mathrm{Nb}$ than the lamprophyres. Their REE patterns have a flatter appearance (Fig. 4), having $(\mathrm{La} / \mathrm{Lu})_{\mathrm{N}}$ values of about three. Upton \& Emeleus (1987) showed chondrite-normalized incompatible element plots for averaged groups of Gardar basaltic-hawaiitic rocks, and noted that the majority of these magmas exhibit a distinct $\mathrm{Nb}$ trough, but that the averaged composition of Gardar basaltic dykes from the Ivittuut area (within the Border Zone of the Archaean craton) lacks a $\mathrm{Nb}$ trough. On this basis, Upton \& Emeleus (1987) suggested that the chemistry of the magmas was controlled by differing lithospheric sources across the margin of the Archaean craton. However, recent work (e.g. Pearce \& Leng 1996; Goodenough 1997) has suggested that $\mathrm{Nb}$ contents in the basaltic dykes are variable across the Gardar Province, and cannot be so simply grouped. It can be seen (Fig. $3 \mathrm{~b}$ and c) that, whereas most of the ne-normative basaltic dykes from the Ivittuut area do not show a significant $\mathrm{Nb}$ anomaly, $\mathrm{Nb}$ troughs are common in the trace element patterns for $h y$-normative basaltic dykes from that area.

Our data for basaltic dykes from the Ivittuut area (Table 1) have been combined with previously published data for the same area (Upton \& Emeleus 1987), and it can be seen that these dykes can be divided into three distinct groups on the basis of their $\mathrm{Zr} / \mathrm{Nb}$ ratios (Fig. 5). Although there is a group of dykes in the Ivittuut area with low $\mathrm{Zr} / \mathrm{Nb}$ ratios of about four, the data also indicate a cluster of dykes with $\mathrm{Zr} / \mathrm{Nb}$ about nine, and a third group with $\mathrm{Zr} / \mathrm{Nb}$ of $16-19$. La/ $\mathrm{Nb}$ ratios (Fig. 6) are low $(<1)$ in the first two groups, but the dykes with high $\mathrm{Zr} / \mathrm{Nb}$ also have high $\mathrm{La} / \mathrm{Nb}(>1)$.

In general, those basaltic dykes with low $\mathrm{Zr} / \mathrm{Nb}$ are $n e-$ normative whereas the higher $\mathrm{Zr} / \mathrm{Nb}$ group are $h y$-normative. Although relative ages are debatable, most field observations suggest that the $h y$-normative dykes are older than the nenormative ones. Similar groups of $h y$-and ne-normative basic rocks have been identified in the East African Rift, where there is no simple relationship between magma alkalinity and spatial and temporal distributions, although in some areas the $h y$ normative rocks appear to be younger (Macdonald et al. 2001).

Upton \& Emeleus (1987) noted that the early and mid-Gardar basalts and hawaiites within the Ketilidian mobile belt, together with those of the late-Gardar Nunarssuit-Isortôq zone, have high $\mathrm{Zr} / \mathrm{Nb}$ ratios of about 18 . In contrast, the late Gardar dykes of the Tugtutôq-Ilímaussaq-Nunataq zone have $\mathrm{Zr} / \mathrm{Nb}$ ratios of $3-$ 7. The dykes of the Tugtutôq-Ilímaussaq-Nunataq zone have been further subdivided by Pearce \& Leng (1996), who noted a subdivision into two groups: one with lower $\mathrm{Zr} / \mathrm{Nb}$ (c. 3.5) in nenormative dykes; and a second with higher $\mathrm{Zr} / \mathrm{Nb}$ (around six) in $q z$-normative dykes that had evolved from $h y$-normative basalts.

It appears that similar groups of Gardar basaltic dykes, characterized by different $\mathrm{Zr} / \mathrm{Nb}$ ratios, can be seen both within the Border Zone of the Archaean craton and within the Ketilidian mobile belt. As a general rule, it seems that the lower $\mathrm{Zr} / \mathrm{Nb}$ ratios may characterize younger Gardar basaltic magmas, and the major control on the geochemistry of these magmas may therefore be temporal rather than spatial. 


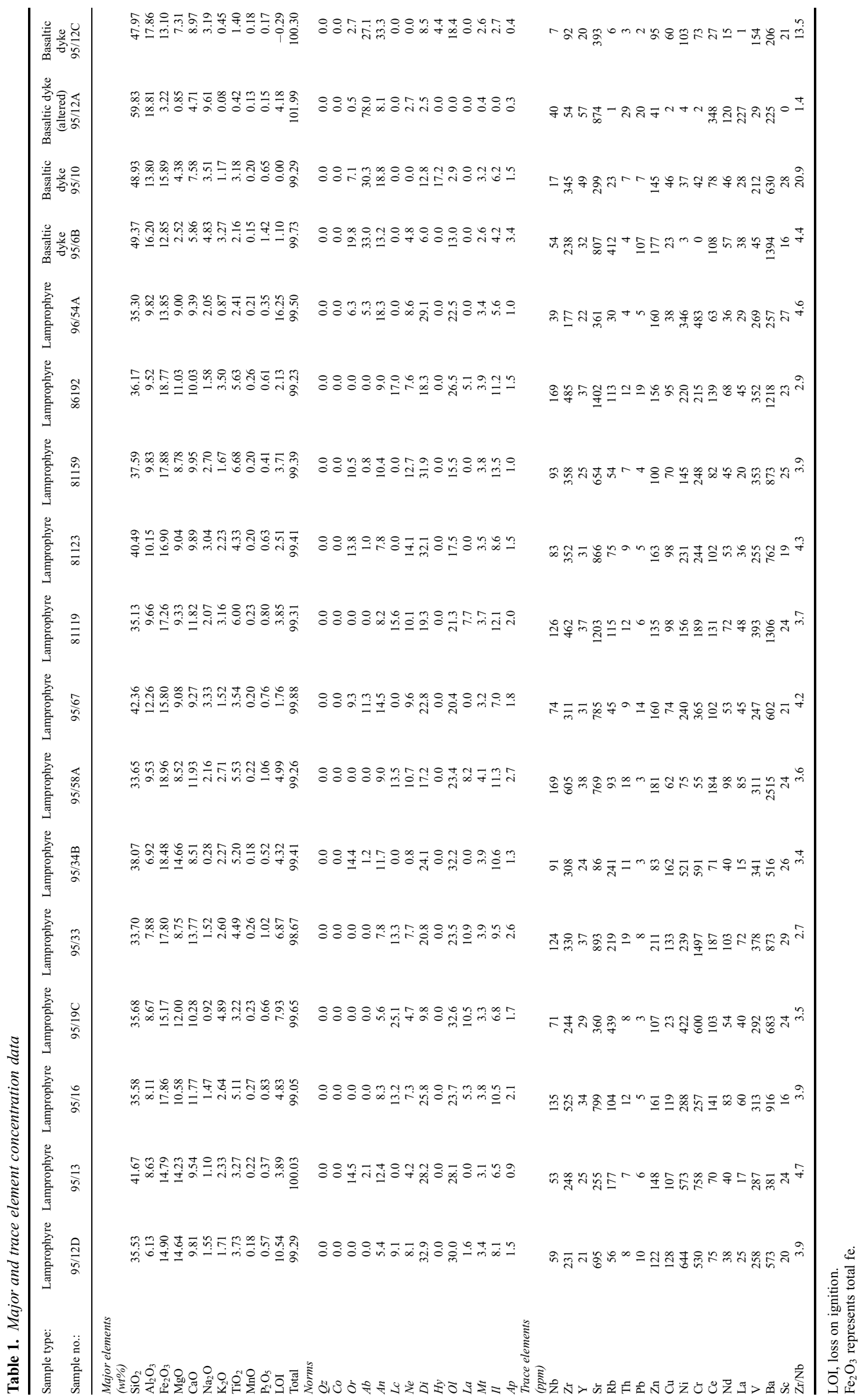




\begin{tabular}{|c|c|c|c|}
\hline 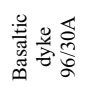 & 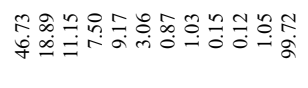 & $\because \because$ m & 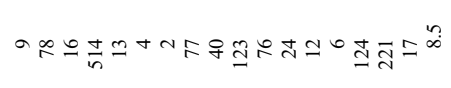 \\
\hline 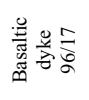 & 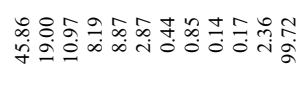 & 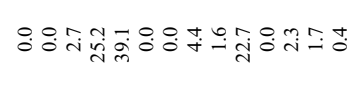 & 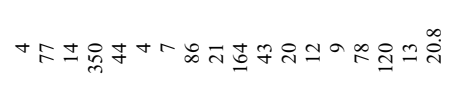 \\
\hline 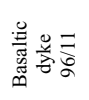 & 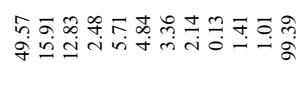 & 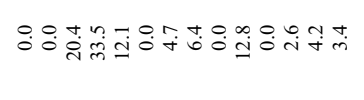 & 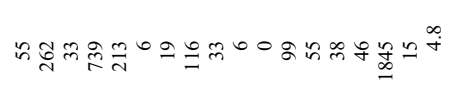 \\
\hline 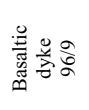 & 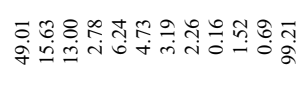 & 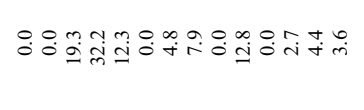 & 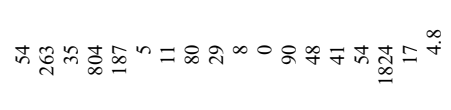 \\
\hline 总产要 & 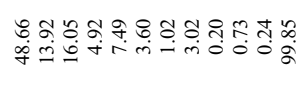 & 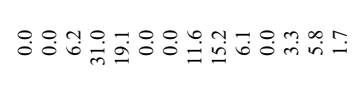 & 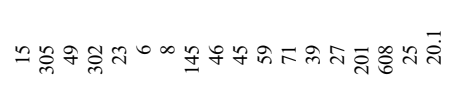 \\
\hline 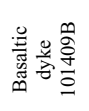 & 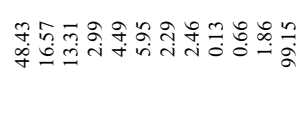 & 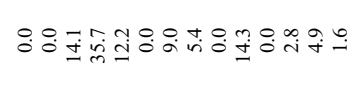 & 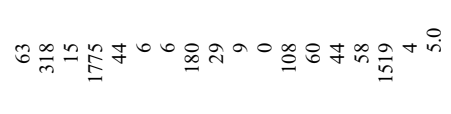 \\
\hline 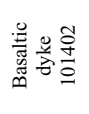 & 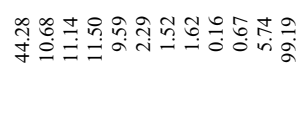 & 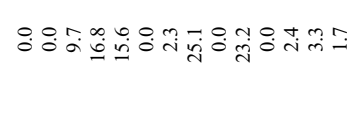 & 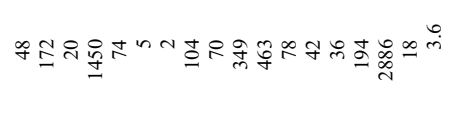 \\
\hline 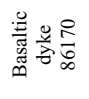 & 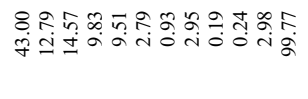 & 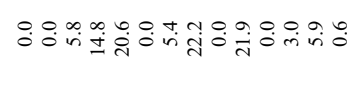 & 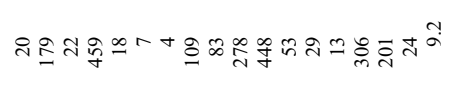 \\
\hline 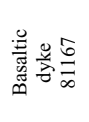 & 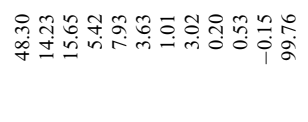 & 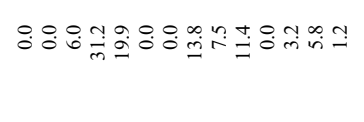 & 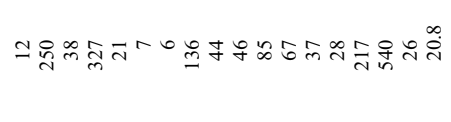 \\
\hline 营 & 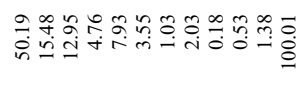 & 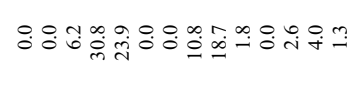 & 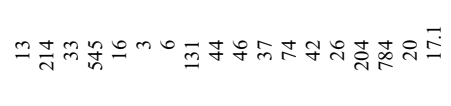 \\
\hline 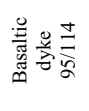 & 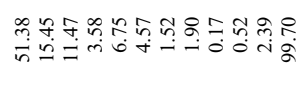 & 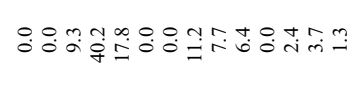 & 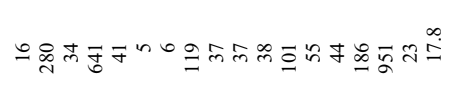 \\
\hline 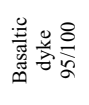 & 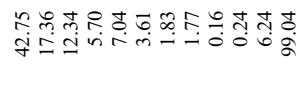 & 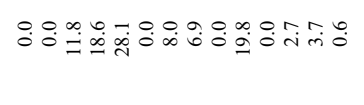 & 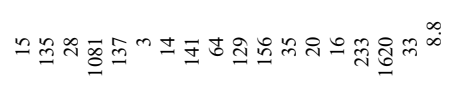 \\
\hline 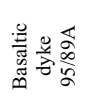 & 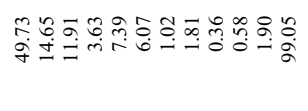 & 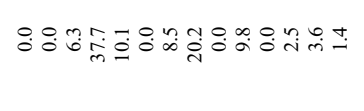 & オேำ \\
\hline 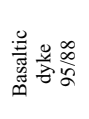 & 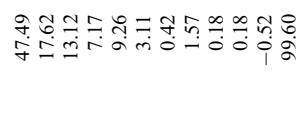 & :ㅁn & 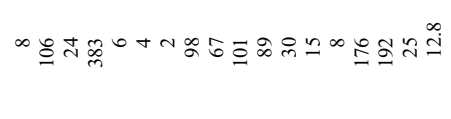 \\
\hline 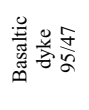 & 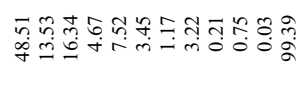 & 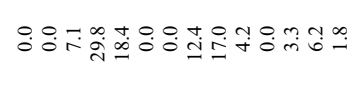 & 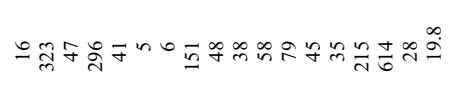 \\
\hline 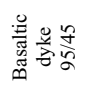 & 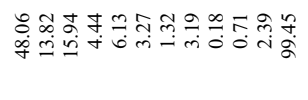 & ¿̊: & 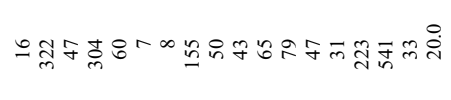 \\
\hline 总善表 & 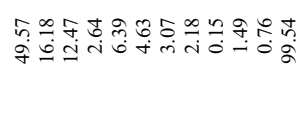 & $\therefore$ & 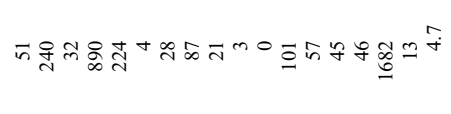 \\
\hline 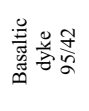 & 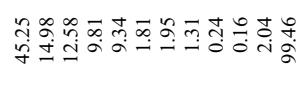 & 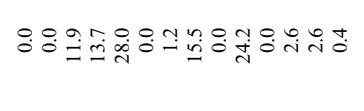 & • \\
\hline 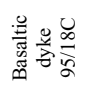 & 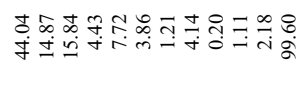 & ㅇำ & 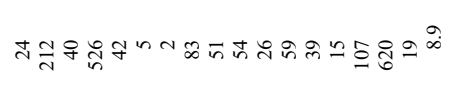 \\
\hline 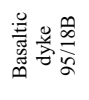 & 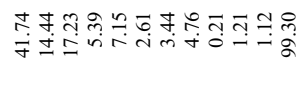 & 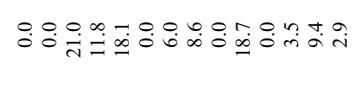 & 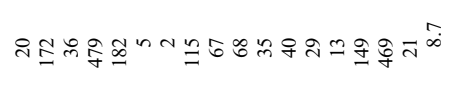 \\
\hline
\end{tabular}



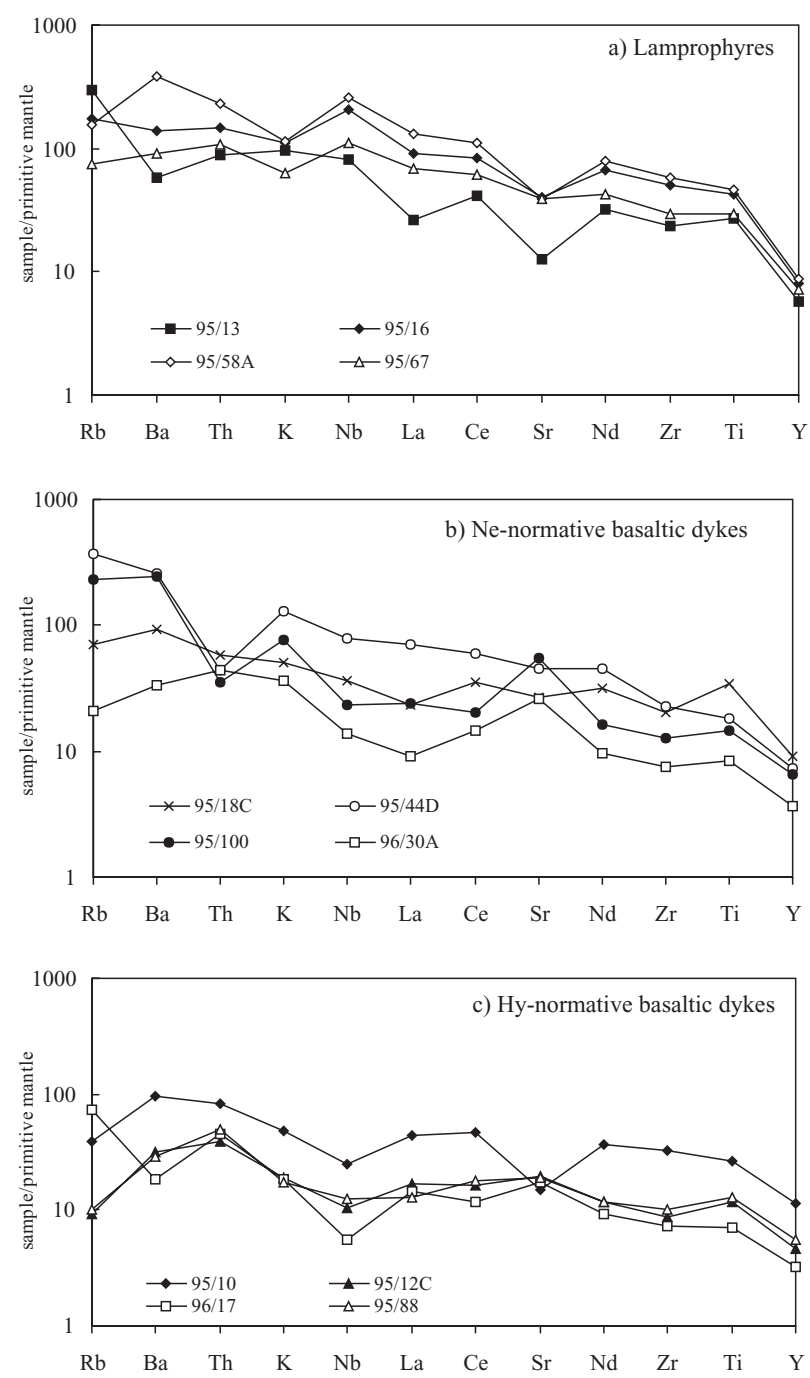

Fig. 3. Primitive-mantle-normalized incompatible element patterns for representative samples from groups of Gardar dykes from the Ivittnut area. Normalizing values from McDonough \& Sun (1995).

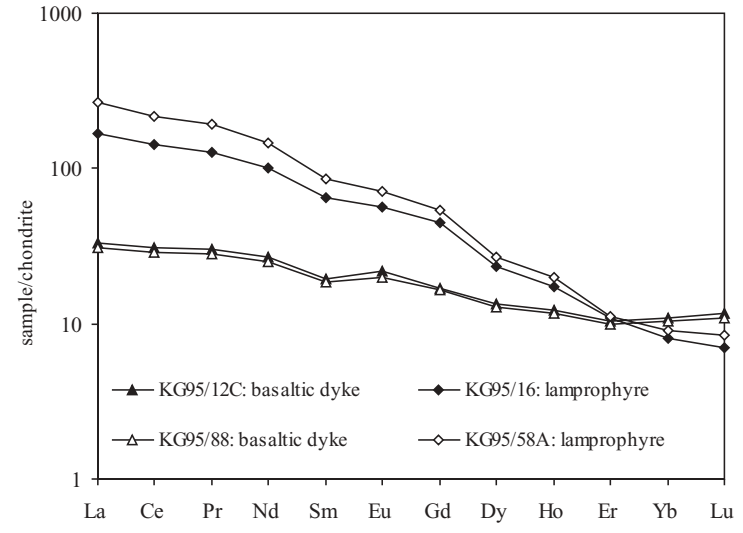

Fig. 4. Chondrite-normalized REE plots for selected samples of Gardar dykes from the Ivittuut area. Normalizing values from Nakamura (1974).

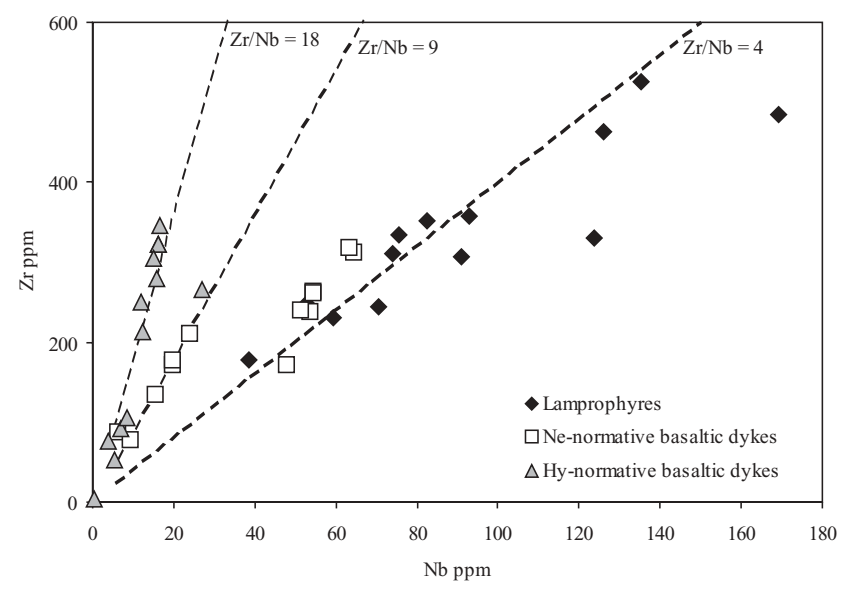

Fig. 5. $\mathrm{Zr} / \mathrm{Nb}$ ratios for the differing groups of Gardar dykes in the Ivittuut area.

Table 2. REE data for selected samples

\begin{tabular}{lrcccc}
\hline $\begin{array}{l}\text { Sample type: } \\
\text { Sample no.: }\end{array}$ & $\begin{array}{c}\text { Lamprophyre } \\
95 / 16\end{array}$ & $\begin{array}{c}\text { Lamprophyre } \\
95 / 58 \mathrm{~A}\end{array}$ & $\begin{array}{c}\text { Basaltic dyke } \\
95 / 12 \mathrm{C}\end{array}$ & $\begin{array}{c}\text { Basaltic dyke } \\
95 / 44 \mathrm{D}\end{array}$ & $\begin{array}{c}\text { Basaltic dyke } \\
95 / 88\end{array}$ \\
\hline REE (ppm) & & & & & \\
$\mathrm{La}$ & 54.9 & 87.3 & 11.0 & 45.5 & 10.2 \\
$\mathrm{Ce}$ & 122.9 & 188.9 & 26.8 & 108.0 & 25.2 \\
$\mathrm{Pr}$ & 15.5 & 23.6 & 3.7 & 13.8 & 3.4 \\
$\mathrm{Nd}$ & 64.2 & 92.2 & 17.0 & 58.0 & 15.9 \\
$\mathrm{Sm}$ & 13.3 & 17.2 & 3.9 & 11.0 & 3.8 \\
$\mathrm{Eu}$ & 4.4 & 5.5 & 1.7 & 4.6 & 1.5 \\
$\mathrm{Gd}$ & 12.2 & 14.9 & 4.7 & 9.8 & 4.6 \\
$\mathrm{Dy}$ & 8.0 & 9.2 & 4.6 & 6.5 & 4.4 \\
$\mathrm{Ho}$ & 1.3 & 1.5 & 0.9 & 1.2 & 0.9 \\
$\mathrm{Er}$ & 2.5 & 2.5 & 2.4 & 2.4 & 2.3 \\
$\mathrm{Yb}$ & 1.8 & 2.0 & 2.4 & 2.1 & 2.3 \\
$\mathrm{Lu}$ & 0.2 & 0.3 & 0.4 & 0.3 & 0.4 \\
\hline
\end{tabular}




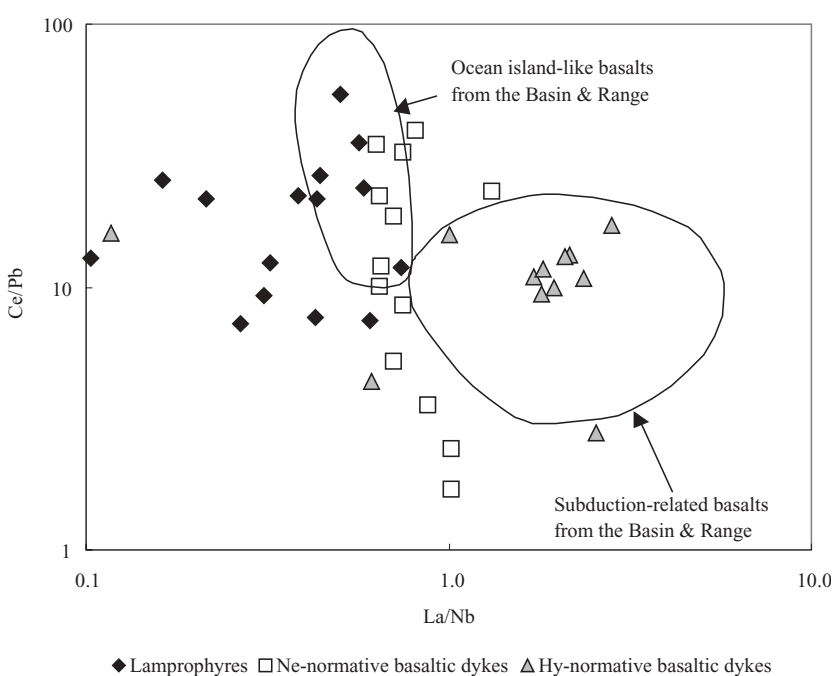

Fig. 6. $\mathrm{Ce} / \mathrm{Pb}-\mathrm{La} / \mathrm{Nb}$ plot for Gardar dykes from the Ivittuut area, showing fields of subduction-like and ocean-island-like basalts after Fitton (1995)

\section{Nd-Sr isotope data for basic and ultrabasic intrusive rocks of the Ivittuut area}

Seven samples of dykes from the Ivittuut area (three lamprophyric and four basaltic dykes) have been analysed for ${ }^{87} \mathrm{Sr} /{ }^{86} \mathrm{Sr}$ and ${ }^{143} \mathrm{Nd} /{ }^{144} \mathrm{Nd}$ as part of a wider study (Goodenough 1997; Goodenough et al. 2000). The data (Table 3) have been corrected to an age of $1280 \mathrm{Ma}$, based on a recent $\mathrm{U}-\mathrm{Pb}$ date on zircons from an olivine dolerite dyke (L. Heaman, pers. comm.). Although the lamprophyres have not been accurately dated, cross-cutting relationships show that they are older than the brown dykes (Berthelsen \& Henriksen 1975). Patchett (1976) suggested, on the basis of $\mathrm{Rb}-\mathrm{Sr}$ whole-rock isochrons, that the lamprophyres of the Ivittuut region dated from 1230 to $1300 \mathrm{Ma}$. It therefore seems reasonable to correct the lamprophyres to $1280 \mathrm{Ma}$ in the absence of more conclusive dating.

One of the lamprophyre samples shows petrographic evidence of being highly altered by the passage of late-stage fluids, and has an implausibly low initial ${ }^{87} \mathrm{Sr} /{ }^{86} \mathrm{Sr}$ (i.e. $<0.699$ ) calculated at $1280 \mathrm{Ma}$, possibly as a result of loss of radiogenic $\mathrm{Sr}$ or the addition of $\mathrm{Rb}$ through metasomatic activity. The other two samples have initial ${ }^{87} \mathrm{Sr} /{ }^{86} \mathrm{Sr}$ of $0.7026-0.7036$ (Fig. 7). Initial ${ }^{143} \mathrm{Nd} /{ }^{144} \mathrm{Nd}$ for these samples ranges from 0.51120 to 0.51124 , giving $\epsilon_{\mathrm{Nd}}$ of between +4.1 and +7.3 . The highest $\epsilon_{\mathrm{Nd}}$ is for the altered sample, and this fits with recent work on the Ivigtut granite (Goodenough et al. 2000) that indicates that late-stage, possibly $\mathrm{F}$ - and $\mathrm{CO}_{2}$-rich fluids in the area had high $\epsilon_{\mathrm{Nd}}$ values.

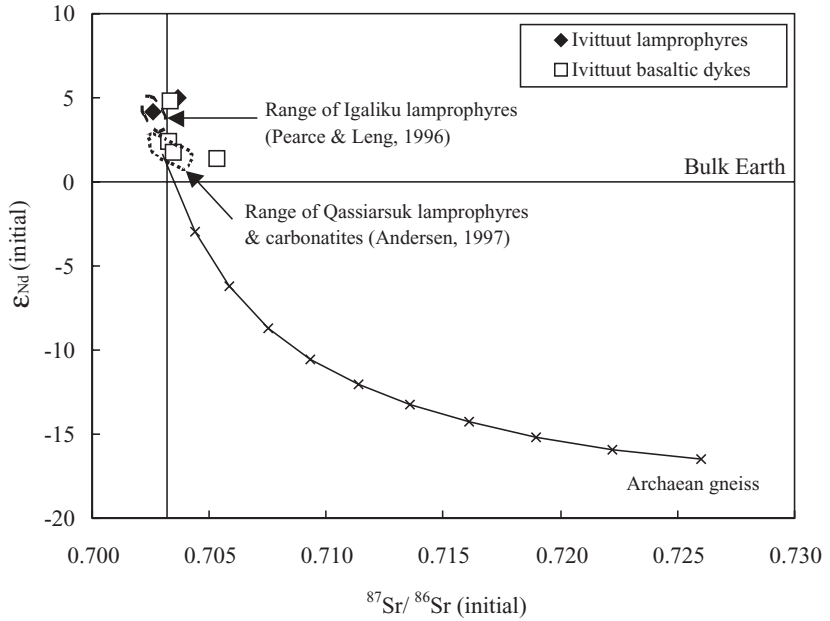

Fig. 7. $\epsilon_{\mathrm{Nd}} \mathrm{v} .{ }^{87} \mathrm{Sr} /{ }^{86} \mathrm{Sr}$ plot for selected samples of Gardar dykes from the Ivittuut area. Data for the Igaliku lamprophyres (Pearce \& Leng 1996) and the Qassiarsuk lamprophyres (Andersen 1997) are shown for comparison. The results of a simple mixing calculation for a typical Gardar basaltic dyke mixing with a typical sample of Archaean gneiss (data from Goodenough 1997) are also shown. Crosses along the curve mark $10 \%$ intervals.

Three samples of olivine dolerites have an average initial ${ }^{87} \mathrm{Sr} /$ ${ }^{86} \mathrm{Sr}$ of 0.7033 , whereas that for a sample from a feldspar-phyric basic dyke is 0.7053 . Initial ${ }^{143} \mathrm{Nd} /{ }^{144} \mathrm{Nd}$ for these samples range from 0.51106 for the feldspar-phyric dyke to 0.51123 for one of the brown dykes $\left(\epsilon_{\mathrm{Nd}}+1.4\right.$ to +4.8$)$.

The isotopic data for the lamprophyric and basaltic dykes overlap to some extent, and are consistent with a mantle origin for the dykes. However, the major and trace element data highlight differences between the two magma types. The lamprophyres represent a very small part of the total volume of Gardar magmas, and although they are more primitive they have higher contents of incompatible elements than the basaltic dykes. Consequently, the two groups of dykes cannot be related by fractional crystallization processes, and appear to have been derived from different mantle sources, or to represent different degrees of partial melting.

Published isotopic data for basic and ultrabasic Gardar rocks are scarce (Fig. 7). Pearce et al. (1997) published some $\mathrm{Sr}$ isotopic data for lamprophyre dykes from Grønnedal-Íka, within the Ivittuut area. These show a range in initial ${ }^{87} \mathrm{Sr} /{ }^{86} \mathrm{Sr}$ of 0.7026-0.7029, comparable with the data presented here. Lamprophyres and carbonatites of the Tugtutôq-Ilímaussaq-Nunataq zone have similar initial ${ }^{87} \mathrm{Sr} /{ }^{86} \mathrm{Sr}$ signatures, with a range of 0.7023-0.7038 (Pearce \& Leng 1996). The majority of Gardar

Table 3. Nd-and Sr-isotopic data for dykes from the Ivigtut area

\begin{tabular}{|c|c|c|c|c|c|c|c|c|c|}
\hline Sample no. & Sample type & ${ }^{87} \mathrm{Rb} /{ }^{86} \mathrm{Sr}$ & ${ }^{87} \mathrm{Sr} /{ }^{86} \mathrm{Sr}$ & ${ }^{147} \mathrm{Sm} /{ }^{144} \mathrm{Nd}$ & ${ }^{143} \mathrm{Nd} /{ }^{144} \mathrm{Nd}$ & $\begin{array}{l}\text { Initial age } \\
\text { (Ma) }\end{array}$ & $\begin{array}{c}{ }^{87} \mathrm{Sr} /{ }^{86} \mathrm{Sr} \\
\text { (initial) }\end{array}$ & $\varepsilon_{\mathrm{Nd}}($ initial) & $T^{\mathrm{Nd}}{ }_{\mathrm{DM}}$ \\
\hline KG95/13 & Lamprophyre & 1.711 & 0.733969 & 0.1271 & 0.512264 & 1280 & 0.702586 & +4.13 & 1574 \\
\hline KG95/12A & Basaltic dyke & 0.003 & 0.703286 & 0.0977 & 0.511927 & 1280 & 0.703231 & +2.37 & 1617 \\
\hline KG95/12C & Basaltic dyke & 0.018 & 0.703756 & 0.1427 & 0.512274 & 1280 & 0.703426 & +1.76 & 1896 \\
\hline KG95/44D & Basaltic dyke & 0.605 & 0.716410 & 0.1134 & 0.512011 & 1280 & 0.705313 & +1.43 & 1742 \\
\hline
\end{tabular}


basaltic rocks have also been shown to have initial ${ }^{87} \mathrm{Sr} /{ }^{86} \mathrm{Sr} c$. 0.703, and this has been taken as representative of the mantle source (e.g. Patchett 1976; Blaxland et al. 1978).

Pearce \& Leng (1996) gave initial $\epsilon_{\mathrm{Nd}}$ (calculated at $1150 \mathrm{Ma}$ ) for the Tugtutôq-Ilímaussaq-Nunataq lamprophyres of +2.6 to +5.1 , overlapping with the Ivittuut lamprophyres. Andersen (1997) presented initial $\epsilon_{\mathrm{Nd}}$ values for lamprophyres from Qassiarsuk, also within the Julianehåb batholith, of +0.7 to +2.4 . Although lower than the values for the Ivittuut lamprophyres, these data overlap with those for the basaltic dykes from Ivittuut. Paslick et al. (1993) reported similar initial $\epsilon_{\mathrm{Nd}}$ values $(+2.1$ to +2.4$)$ for basaltic lavas of the Eriksfjord Formation, erupted through the Ketilidian belt.

The isotopic compositions of most of the basic rocks from the Ivittuut area clearly fall within the range considered to represent the mantle source for Gardar magmas (Blaxland et al. 1978; Andersen 1997), suggesting that these magmas were relatively unaffected by crustal contamination. However, the unusually high initial ${ }^{87} \mathrm{Sr} /{ }^{86} \mathrm{Sr}$ value for the feldspar-phyric basic dyke may indicate a component of crustal assimilation in this sample. Pearce \& Leng (1996) noted that crustal contamination within the Igaliko dykes showed up clearly through higher initial ${ }^{87} \mathrm{Sr} /$ ${ }^{86} \mathrm{Sr}$ ratios. However, in their study, as in the present work, examples of both $h y$ - and ne-normative dykes had initial ${ }^{87} \mathrm{Sr} /$ ${ }^{86} \mathrm{Sr}$ of $c$. 0.703 . This is taken as further evidence that the differing geochemical features of these groups were derived from the mantle source, and not through crustal contamination.

The spread of isotopic data for basic and ultrabasic Gardar dykes is consistent with derivation from a slightly enriched mantle source, with ${ }^{87} \mathrm{Sr} /{ }^{86} \mathrm{Sr}$ of around 0.703 and $\epsilon_{\mathrm{Nd}}$ of +2 to +5 . There is no evidence for the presence of a high ${ }^{87} \mathrm{Sr} /{ }^{86} \mathrm{Sr}$, low $\epsilon_{\mathrm{Nd}}$ enriched mantle source, as has been described beneath some examples of Archaean cratons (e.g. Menzies \& Halliday 1988). Furthermore, there is no evidence for any systematic variation in isotopic ratios between Gardar basic rocks within the craton and those within the adjacent Ketilidian mobile belt. This implies that the isotopic compositions of primitive Gardar magmas were not controlled by derivation from isotopically distinct sources in lithospheric mantle beneath the Archaean craton and the Ketilidian mobile belt.

$\mathrm{Sm}-\mathrm{Nd}$ model ages relative to depleted mantle (DM) were calculated for the basic rocks of the Ivittuut area. These model ages are not necessarily expected to record the emplacement age of the magmas, as this would imply (1) that magma generation was the only process to have affected the $\mathrm{Sm} / \mathrm{Nd}$ ratio and (2) that the magmas were derived solely from a reservoir resembling the DM model. Neither assumption can be presumed to be correct, but, nevertheless, important information can be drawn from $\mathrm{Sm}-\mathrm{Nd}$ model ages. All the dykes have model ages that are older than the best estimate of their emplacement ages (around $1280 \mathrm{Ma}$; L. Heaman, pers. comm.). Model ages for the lamprophyres range from 1285 to $1574 \mathrm{Ma}$, suggesting either (1) that they have undergone a small but variable increase in the $\mathrm{Sm} /$ $\mathrm{Nd}$ ratio through post-emplacement alteration, or (2) that they were derived from sources similar to, or slightly more enriched than, the DM model. The younger basaltic dykes have older model ages of 1520-1896 Ma, suggesting that they suffered a greater degree of post-emplacement alteration or that they incorporated a greater amount of material from sources that had lower ${ }^{143} \mathrm{Nd} /{ }^{144} \mathrm{Nd}$ than the DM model at $1280 \mathrm{Ma}$. As $\mathrm{Sm} / \mathrm{Nd}$ is generally considered robust through all but the most extreme alteration processes, it seems most likely that the Sm-Nd data indicate variable involvement of one or more relatively enriched sources.
As discussed above, the lamprophyric and basaltic magmas are believed to have been relatively unaffected by crustal contamination, as their isotopic ratios fall within the 'mantle range' for Gardar magmas. We therefore suggest that the Nd model ages may represent the involvement of a mantle source that had undergone enrichment processes before the onset of Gardar rifting.

\section{Discussion}

The geochemistry of the Gardar basic and ultrabasic rocks presented above, including the positive initial $\epsilon_{\mathrm{Nd}}$ values, fits with the commonly accepted view that these magmas were derived from the mantle, with negligible crustal contamination (Upton \& Emeleus 1987). On the basis of the data presented above, we are able to draw some conclusions about the mantle sources.

The lamprophyres of the Ivittuut area have trace element patterns similar to those of Gardar lamprophyres lying within the Julianehåb batholith, all of which show a positive $\mathrm{Nb}$ anomaly when normalized to primitive mantle. The lamprophyres investigated in this study have low $\mathrm{Zr} / \mathrm{Nb}$ ratios and high $\mathrm{Ce} / \mathrm{Y}$ ratios, similar to those of OIB (Fitton et al. 1988). The extreme enrichment of some of the lamprophyres in certain incompatible elements can be explained either by very small degrees of partial melting of a relatively depleted mantle source, or by larger degrees of melting of a source that had already been enriched in the incompatible elements.

The basaltic dykes around Ivittuut can be split into two groups on the basis of their trace element patterns and normative characters: $h y$-normative dykes show a negative $\mathrm{Nb}$ anomaly, with high $\mathrm{Zr} / \mathrm{Nb}$ and $\mathrm{La} / \mathrm{Nb}$ ratios; whereas many of the nenormative dykes have no clear $\mathrm{Nb}$ anomaly, and lower $\mathrm{Zr} / \mathrm{Nb}$ and $\mathrm{La} / \mathrm{Nb}$ ratios (Fig. $3 \mathrm{~b}$ and c). The average trace-element composition for $h y$-normative dykes from the Ivittuut area is similar to that given for other mid-Gardar dykes by Upton \& Emeleus (1987), but they did not present any data that match those for the ne-normative dykes. However, the differing trace element patterns for the Ivittuut ne-and hy-normative dykes are similar to those seen in low $\mathrm{Zr} / \mathrm{Nb}$ and high $\mathrm{Zr} / \mathrm{Nb}$ Igaliko dykes, respectively (Pearce \& Leng 1996). We conclude that there are no systematic differences in the trace element patterns that can be directly related to whether the dykes were intruded into Archaean or Proterozoic (Ketilidian) basement, and thus no evidence that the Gardar magmas in the two areas were derived from different mantle sources. Similarly, isotopic ratios for the dykes of the Ivittuut area overlap with those for dykes from within the Ketilidian mobile belt, confirming that they were derived from comparable mantle sources.

$\mathrm{Nd}$ model ages for the Ivittuut dykes range between 1900 and $1285 \mathrm{Ma}$, suggesting that $\mathrm{Sm} / \mathrm{Nd}$ fractionation in the mantle from which these dyke magmas were derived began after $1900 \mathrm{Ma}$. The main tectonic event in the region, before Gardar rifting, was the Ketilidian orogeny, which has been dated between 1855 and $1780 \mathrm{Ma}$ (McCaffrey et al. 2000). It is thus possible that the $\mathrm{Nd}$ model ages for the basic dykes may indicate an enrichment of the mantle source related to that orogeny. Chadwick \& Garde (1996) suggested that, during the Ketilidian orogeny, there was northward-directed subduction beneath the edge of the Archaean craton. This could have led to enrichment of the mantle wedge above the subduction zone by slab-derived fluids or hydrous silicic melts that were deficient in $\mathrm{Nb}$ but relatively LREE enriched (Saunders \& Tarney 1984; Fitton 1995; Prouteau et al. 2001). Subduction-related magmas typically have high $\mathrm{La} / \mathrm{Nb}$ (>1) and low $\mathrm{Ce} / \mathrm{Pb}$ ratios (Thompson et al. 1983; Fitton 1995). 
As shown in Fig. 6, these ratios for the Gardar hy-normative basalts are similar to those observed in subduction-related basalts from the Basin and Range Province (Fitton 1995).

High $\mathrm{La} / \mathrm{Nb}$ ratios $(>1)$ are found in many continental flood basalts (Thompson et al. 1983), as well as in subduction-related basalts. Although OIB-type magmas may represent uncontaminated melts from a mantle plume, high $\mathrm{La} / \mathrm{Nb}$ magmas require another explanation, usually involving assimilation of crust or lithospheric mantle (Gibson et al. 1999).

The high $\mathrm{La} / \mathrm{Nb}$ and $\mathrm{Zr} / \mathrm{Nb}$ ratios of the hy-normative Gardar rocks could be attributed to contamination of the magmas by crustal rocks formed above the Ketilidian subduction zone. However, as discussed above, the isotopic data do not indicate any significant amount of crustal contamination. The crustal rocks, both Archaean gneisses and Proterozoic granites, had considerably lower $\epsilon_{\mathrm{Nd}}$ values and higher ${ }^{87} \mathrm{Sr} /{ }^{86} \mathrm{Sr}$ ratios at $1280 \mathrm{Ma}$ than those seen in the Gardar magmas (Andersen 1997; Goodenough 1997). Simple mixing calculations (Fig. 7) indicate that incorporation of $10 \%$ of a crustal component (represented by a sample of Archaean gneiss; Goodenough 1997) into a typical Gardar basaltic magma would significantly alter the initial isotopic ratios, giving $\epsilon_{\mathrm{Nd}}<0$ and ${ }^{87} \mathrm{Sr} /{ }^{86} \mathrm{Sr}$ c. 0.705 . However, much greater amounts of crustal contamination would be required to produce the observed variation in $\mathrm{Zr} / \mathrm{Nb}$ ratios between hy-normative and ne-normative basaltic magmas. Both hy-normative and ne-normative Gardar basaltic rocks typically have $\epsilon_{\mathrm{Nd}}$ values $>+1$ and ${ }^{87} \mathrm{Sr} /{ }^{86} \mathrm{Sr}$ c. 0.703 . It therefore seems unlikely that the low $\mathrm{Nb}$ contents in the $h y$-normative basaltic rocks can be attributed to a significant component of crustal contamination.

As crustal contamination does not seem to have been a significant factor in the genesis of the Gardar magmas, it appears that the low $\mathrm{Nb}$ contents in the hy-normative magmas were derived from the lithospheric mantle source. We suggest that the lithospheric mantle may have been enriched by $\mathrm{Nb}$ - and $\mathrm{Ta}$ deficient fluids derived from the Ketilidian subduction zone, and that this subsequently provided the source for some of the Gardar basaltic magmas, as suggested by Upton (1996). The nenormative basaltic magmas may represent the effects of deeper melting, possibly involving a sub-lithospheric mantle source.

Following the Ketilidian orogeny, the area was subsequently unaffected by tectonic activity until the onset of Gardar rifting, at around $1300 \mathrm{Ma}$. This rifting was localized along the boundary between the craton and the younger, thinner lithosphere of the mobile belt. This localized melting and lithospheric thinning may have led to volatile-rich, small fraction, carbonatitic partial melts rising from the asthenospheric mantle and becoming frozen in as metasomites in the lithospheric mantle (Macdonald \& Upton 1993). These metasomites were very fusible and accelerated the onset of melting during rifting, as such remelting requires a smaller temperature rise, or a smaller amount of extension, than that required for dry melting (McKenzie 1989). Melts of these metasomites were volatile rich and hence ascended rapidly through the lithosphere, forming the lamprophyre magmas. Larger-scale melting of the lithospheric mantle produced the basaltic magmas.

\section{Conclusions}

The geochemical data do not indicate a systematic difference between the geochemistry of Gardar basic dykes within the Archaean Border Zone and within the Ketilidian mobile belt, and there is thus no evidence for a lithospheric control on spatial variation in Gardar geochemistry. It appears that basic magmas across the Gardar Province were derived from a heterogeneous, enriched lithospheric mantle reservoir.

The lithospheric mantle beneath the Gardar Province may have been metasomatized by subduction-related fluids or melts during Ketilidian subduction, around $1800 \mathrm{Ma}$. The area was subsequently essentially unaffected by tectonic activity until the onset of Gardar rifting, at around $1300 \mathrm{Ma}$, at which time localized melting and lithospheric thinning led to volatile-rich, small fraction, carbonatitic partial melts rising up from the asthenospheric mantle and becoming frozen in as metasomites in the lithospheric mantle (Macdonald \& Upton 1993). Remelting of these metasomites produced the Gardar lamprophyre magmas.

During the early phases of Gardar rifting, the basaltic magmas were derived by larger-scale partial melting of the lithospheric mantle. This lithospheric mantle had remained largely unaffected by melting or tectonism since the Ketilidian orogeny some $500 \mathrm{Ma}$ earlier, and thus the basaltic magmas exhibited some of the characteristics of supra-subduction zone magmas, such as high large ion lithophile elements and LREE and low $\mathrm{Nb}$ concentrations. As rifting and lithospheric thinning progressed, an asthenospheric mantle component may have become increasingly involved in the source of some of the basaltic magmas, as is indicated by the higher $\mathrm{Nb}$ concentrations in some later Gardar basic rocks.

On the basis of the above data, we conclude that the Gardar magmas in the Border Zone of the Archaean craton were not derived from an ancient (i.e. Archaean), enriched lithospheric keel, but that the lithosphere in this area was affected by subduction processes related to the Ketilidian orogeny. The lithospheric mantle then retained this subduction-related signature until the onset of Gardar rifting some $500 \mathrm{Ma}$ later.

Much of this work was undertaken by K.G. during the term of a NERC research studentship at the University of Edinburgh. I. Parsons, W. Brown, A. Finch and D. Stirling are thanked for their greatly appreciated advice and company in the field during 1995 and 1996. D. James, A. Kelly and V. Gallagher are thanked for their assistance with analytical work. A. Kerr, L. M. Larsen and N. Pearce provided extremely constructive and helpful reviews of an earlier version of the manuscript. S. Gibson also contributed many constructive comments.

\section{References}

ANDERSEN, T. 1997. Age and petrogenesis of the Qassiarsuk carbonatite-alkaline silicate volcanic complex in the Gardar rift, South Greenland. Mineralogical Magazine, 61, 499-513.

BAILEY, J.C. 1980. Formation of cryolite and other aluminofluorides: a petrologic review. Bulletin of the Geological Society of Denmark, 29, 1-45.

BEDFORD, C. 1989. Mineralogy, geochemistry and petrogenesis of the GrønnedalÍka alkaline igneous complex, SW Greenland. $\mathrm{PhD}$ thesis, University of Durham.

Berthelsen, A. 1962. On the geology of the country around Ivittuut, SW Greenland. Geologische Rundschau, 52, 269-280.

Berthelsen, A. \& Henriksen, N. 1975. Geological map of Greenland 1:100 000. Ivittuut 61 V.1 Syd. Grønlands Geologiske Undersøgelse, Copenhagen (Meddelelser om Grønland).

Blaxland, A.B., Van Breemen, O., Emeleus, C.H. \& Anderson, J.G. 1978. Age and origin of the major syenite centres in the Gardar Province of South Greenland: $\mathrm{Rb}-\mathrm{Sr}$ studies. Geological Society of America Bulletin, 89, $231-244$.

Chadwick, B. \& Garde, A.A. 1996. Palaeoproterozoic oblique plate convergence in South Greenland: a reappraisal of the Ketilidian orogen. In: BREwer, T.S. (ed.) Precambrian Crustal Evolution in the North Atlantic Region. Geological Society, London, Special Publications, 112, 179-196.

Emeleus, C.H. 1964. The Grønnedal-Íka Alkaline Complex, South Greenland. Bulletin Grønlands Geologiske Undersøgelse, 45.

Emeleus, C.H. \& Upton, B.G.J. 1976. The Gardar period in southern Greenland. In: Escher, A. \& WATt, W.S. (eds) The Geology of Greenland. Geological Survey of Greenland, Copenhagen, 153-181. 
Fitton, J.G. 1995. Coupled molybdenum and niobium depletion in continental basalts. Earth and Planetary Science Letters, 136, 715-721.

Fitton, J.G., James, D., Kempton, P.D., Ormerod, D.S. \& Leeman, W.P. 1988. The role of lithospheric mantle in the generation of late Cenozoic basic magmas in the Western United States. Journal of Petrology, Special Lithosphere Issue, 331-349.

Fitton, J.G., Saunders, A.D., Larsen, L.M., Hardarson, B.S. \& Norry, M.J. 1998. Volcanic rocks from the southeast Greenland margin at $63 \mathrm{~N}$ : composition, petrogenesis and mantle sources. In: SAunders, A.D., LARSEN, H.C. \& Wise, S.W. JR (eds) Proceedings of the Ocean Drilling Program, Scientific Results. Ocean Drilling Program, College Station, TX, 152, 331-350.

Gibson, S.A., Thompson, R.N., Leonardos, O.H., Dickin, A.P. \& Mitchell, J.G. 1999. The limited extent of plume-lithosphere interactions during continental flood-basalt genesis: geochemical evidence from Cretaceous magmatism in southern Brazil. Contributions to Mineralogy and Petrology, 137, 147-169.

Goodenough, K.M. 1997. Geochemistry of Gardar intrusions in the Ivittuut area, south Greenland. $\mathrm{PhD}$ thesis, Edinburgh University.

Goodenough, K.M., Upton, B.G.J. \& Ellam, R.M. 2000. Geochemical evolution of the Ivittuut granite, South Greenland: a fluorine-rich 'A-type' intrusion. Lithos, 51, 205-221.

Le Maitre, R.W. 1989. A Classification of Igneous Rocks and Glossary of Terms. Blackwell Scientific, Oxford.

Macdonald, R. \& Upton, B.G.J. 1993. The Proterozoic Gardar rift zone, south Greenland: comparisons with the East African Rift System. In: PrICHARD, H.M., Alabaster, T., Harris, N.B.W. \& Neary, C.R. (eds) Magmatic Processes and Plate Tectonics. Geological Society, London, Special Publications, 76, 427-442.

Macdonald, R., Rogers, N.W., Fitton, J.G., Black, S. \& Smith, M. 2001. Plume-lithosphere interactions in the generation of the basalts of the Kenya Rift, East Africa. Journal of Petrology, 42, 877-900.

McCaffrey, K., Chadwick, B., Garde, A., Grocott, J. \& Hamilton, M.A. 2000. Tectonothermal evolution of the Palaeoproterozoic Ketilidian orogen, South Greenland. Unpublished conference abstract, Geoscience 2000, Manchester.

McDonough, W.F. \& Sun, S.-S. 1995. The composition of the Earth. Chemical Geology, 120, 223-255.

McKenZIE, D. 1989. Some remarks on the movement of small melt fractions in the mantle. Earth and Planetary Science Letters, 95, 53-72.

Menzies, M.A. \& Halliday, A. 1988. Lithospheric mantle domains beneath the Archaean and Proterozoic crust of Scotland. Journal of Petrology, Special Lithosphere Issue, 275-302.

Nakamura, N. 1974. Determination of REE, Ba, Fe, $\mathrm{Mg}, \mathrm{Na}$ and $\mathrm{K}$ in carbonaceous and ordinary chondrites. Geochimica et Cosmochimica Acta, 38, $757-775$.

Paslick, C.R., Halliday, A.N., Davies, G.R., Mezger, K. \& Upton, B.G.J. 1993. Timing of Proterozoic magmatism in the Gardar Province, southern Greenland. Geological Society of America Bulletin, 105, 272-278.

PAtchetT, P.J. 1976. Rb-Sr geochronology and geochemistry of Proterozoic basic intrusions in Sweden and South Greenland. $\mathrm{PhD}$ thesis, University of Edinburgh.

Pauly, H. \& Bailey, J.C. 1999. Genesis and Evolution of the Ivigtut Cryolite Deposit, SW Greenland. Meddelelser om Grønland, 37.

Pearce, N.J.G. \& Leng, M.J. 1996. The origin of carbonatites and related rocks from the Igaliko Dyke Swarm, Gardar Province, South Greenland: field, geochemical, and $\mathrm{C}-\mathrm{O}-\mathrm{Sr}-\mathrm{Nd}$ isotope evidence. Lithos, 39, 21-40.

Pearce, N.J.G., Leng, M.J., Emeleus, C.H. \& Bedford, C.M. 1997. The origins of carbonatites and related rocks from the Grønnedal-Íka nepheline syenite complex, south Greenland: $\mathrm{C}-\mathrm{O}-\mathrm{Sr}$ isotope evidence. Mineralogical Magazine, 61, 515-529.

Prouteau, G., Scaillet, B., Pichavant, M. \& Maury, R. 2001. Evidence for mantle metasomatism by hydrous silicic melts derived from subducted oceanic crust. Nature, 410, 197-200.

Rock, N.M.S. 1987. The nature and origin of lamprophyres: an overview. In: Fitton, J.G. \& Upton, B.G.J. (eds) Alkaline Igneous Rocks. Geological Society, London, Special Publications, 30, 191-226.

SAUnders, A.D. \& TARnEY, J. 1984. Geochemical characteristics of basaltic volcanism within back-arc basins. In: KoKelaAR, B.P. \& Howells, M.F. (eds) Marginal Basin Geology. Geological Society, London, Special Publications, 16, 59-76.

Thompson, R.N., Morrison, M.A., Dickin, A.P. \& Hendry, G.L. 1983. Continental flood basalts ... arachnids rule OK?. In: HAwKesworTH, C.J. \& Norry, M.J. (eds) Continental Basalts and Mantle Xenoliths. Shiva, Nantwich, 158-185.

Upton, B.G.J. 1960. The Alkaline Complex of Kûngnât Fjeld, South Greenland. Bulletin Grønlands Geologiske Undersøgelse, 27.

Upton, B.G.J. 1974. The alkaline province of Southwest Greenland. In: SøRENSEN, H. (ed.) The Alkaline Rocks. Wiley, New York, 231-238.

Upton, B.G.J. 1996. Anorthosites and troctolites of the Gardar magmatic province. In: Demaiffe, D. (ed.) Petrology and Geochemistry of Magmatic Suites of Rocks in the Continental and Oceanic Crusts. A Volume Dedicated to Professor Jean Michot. Université Libre de Bruxelles, Brussels; Royal Museum for Central Africa, Tervuren, 19-34.

Upton, B.G.J. \& Blundell, D.J. 1978. The Gardar Igneous Province: evidence for Proterozoic continental rifting. In: NeumanN, E.R. \& RAMberG, I.B. (eds) Petrology and Geochemistry of Continental Rifts. Reidel, Dordrecht, $163-172$.

Upton, B.G.J. \& Emeleus, C.H. 1987. Mid-Proterozoic alkaline magmatism in southern Greenland: the Gardar province. In: FitTON, J.G. \& UPTON, B.G.J. (eds) Alkaline Igneous Rocks. Geological Society, London, Special Publications, 30, 449-471.

Walsh, N.M., Buckley, F. \& Barker, J. 1981. The simultaneous determination of the rare-earth elements in rocks using inductively coupled plasma source spectrometry. Chemical Geology, 33, 141-153.

WindLEy, B.F. 1991. Early Proterozoic collision tectonics, and rapakivi granites as intrusions in an extensional thrust-thickened crust: the Ketilidian orogen, South Greenland. Tectonophysics, 195, 1-10. 